\title{
Learning Through Virtual Environment
}

\author{
S. Pothumani, R. Velvizhi, S. Amudha
}

\begin{abstract}
The evolution of the technology takes the education to next level, where it makes the learning process more interesting and attractive. The Virtual Reality plays an important role in this evolution. The main aim of this work is to enhance the learning ability in students through virtual environment by developing an education based game. In this work, the virtual reality device-Wii mote has been used for the learning process, and also for answering the questions in the different levels of game. The learning process also involves the speech synthesis. This helps the visually impaired people to learn without others help and it also motivates even the average students to participate more actively in learning process. The game has been further divided as easy, medium and difficult levels. So the learning ability of each student can be easily tested and further steps can be taken in order to motivate them, and to optimize their learning skill. Thus, this work motivates the students for learning and to exalt their learning ability.
\end{abstract}

KEYWORDS: Virtual Environment, Virtual Reality, Wii mote, Speech Synthesis.

\section{INTRODUCTION}

Game-based learning is an educational technique that includes educational material or values of teaching into video games to engage learners. The use of this technique has been progressively the subject of research in latest years in the sector of natural science and technology. Learning through digital games not only increases motivation, active learning, and provides possibilities for personal teaching, but also decreases students ' teaching stress. Virtual Reality (VR) is an educational instrument that is strong and more promising because its distinctive technological features distinguish it from other apps [1-3].

Virtual reality is basically characterized by three ideas, which include the immersion, interaction and imagination. All these three factors permit the individual to participate more actively in the learning process without any distractions. VR devices are not only used for games and education, but also for the training process, which reduces the cost of equipments and also avoids the wastage of the products. VR devices are mostly used in military and medical training. In the medical field, when the training has to be given for the individuals in the field of biological cell injection [4-6]. Then it involves more wastage of cells, because of the restrictions of the cells, where one cell cannot be used for another time, and also all the equipments used for these training are more costly. So, when the training is given for the individuals under the virtual environment, it adds more advantage, where they can undergo the training for multiple number of times than in the real-time and can avoid the wastage, by reusing the virtual objects [7-9].

The main motivation behind this work is that, when the learning process is made along with the pictures than with the words, it adds more advantage, and also increases the memory power of the students. It also gives more clarity to the students about the concepts.

\section{LITERATURE SURVEY}

Abdul-Hadi G. Abulrub et al.[10] explained the virtual reality idea and demonstrated how innovative technology can be used through real-life case studies to produce creative learning and virtual environments. Sandra Dutra Piovesan et al.[11] developed an educational software with formal language subjects involving Automatons, Regular Expressions and Minimization of Automatons, which interacts directly with the object in $3 \mathrm{D}$, making the subject more interesting for the students and making learning easier. The importance of VR in education and mainly the importance and advantages of training in Military using VR tools have been explained by Joseph Psotka et al. Jiangfan Feng et al. explained the necessity of applying VR technology in GIS education and through the case studies such as Geographic Process Simulation and Virtual Campus, suggested that the education is not limited to the class room. Chih-Hsiao Tsai et al suggested a scheme for facilitating and motivating learners by offering appropriate $3 \mathrm{D}$ visual products as well as assessing the impacts of particular operational experiences. Usability and learning outcomes of the cubic net aided teaching scheme were provided using Kinect sensor. Ali Rahimi et al suggested the technique to discover Iranian EFL students ' approach and feeling about VR and its impact on the Iranian language teaching society in three stages of private beliefs, technical problems and pedagogical elements. [12-15].

Veljko B. Petrovic et al. [16] discussed about the usage of Wii Peripherals for facilitating learning process in CS education, which helps the students to approach the problems in a creative way. Joao Gameiro et al. developed the game based learning environment, where the sign language is learned using the Kinect, which has been mainly proposed for the listeners of deaf persons. Evgenia Boutsika et al. [17-19] used the Kinect as a learning auxiliary tool for teaching children with autism, in order to improve the behavior of children, such as making positive statements to each other.

Revised Manuscript Received on August 22, 2019.

S. Pothumani, Department of CSE, Bharath Institute of Higher Education and Research, Chennai, Tamilnadu, India.

R. Velvizhi, Department of CSE, Bharath Institute of Higher Education and Research, Chennai, Tamilnadu, India.

S. Amudha, Department of CSE, Bharath Institute of Higher Education and Research, Chennai, Tamilnadu, India. 


\section{VIRTUAL REALITY}

Virtual reality has three I's, immersion, communication, and fantasy. Immersion feeling of being in an environment; it can be a purely mental state or it can be achieved by physical means. Physical immersion includes entering the parts of the body through the use of technology into a medium, synthetic stimulus, this does not mean all senses or that the whole body is submerged. A state of deep participation in mental immersion, suspension of disbelief, participation [20].

Imagination involves exploring a virtual environment in which it explains how engaged the person is in his job. If the customer has participated in the virtual environment(VE) and is able to interact immediately as a consequence of the implementation, the customer can passively or actively operate the VE. Interaction involves the customer manipulating virtual items. Gloves are devices that create this feeling.

\section{PROPOSED WORK}

Visualization is a key element in the learning process, where a picture is worth a thousand words. So in order to improve the memory, the texts are given along with the pictures for each concepts. It consists of two parts: learning mode and test mode. In the learning mode, the concepts from different subjects such as history, geography and physics are explained by using the pictures. The Speech Synthesis plays here an important role, where the machine generates the spoken language as the output for the written input. So it helps even the blind people to learn easily without others help. In the test mode, students need to answer the questions with the Wiimote, which is converted as an Air mouse, with the help of the GlovePie. Since this process acts similar to playing a game, students will actively participate in the learning process, without any learning pressure. This kind of education lifts the level of education to one step higher in the future, if it has been implemented in all the schools.

\section{A. Combining the concepts with the pictures}

Initially the concepts are taken from the books, and for those concepts the related pictures are gathered. Then in the learning process, the concepts are explained along with the pictures through the speech synthesis. So when something is learnt along with the pictures, it makes the individual to have in memory for a long time, where it also gives the clear clarification of the concepts [21].

\section{B. Speech Synthesis}

Speech synthesis is achieved with the help of the Free Text to Speech Software. This FreeTTSsoftware converts the written text input into the speech. The FreeTTSSpeakable is an api in this respect. Anything that is a text source that requires to be spoken to FreeTTS will be transformed to a FreeTTSSpeakable first. This interface is implemented by Free TTS Speakable Impl. This application will wrap as a FreeTTSSpeakable the most popular input types. A speech to be spoken is provided a FreeTTSSpeakable. The Voice is the main FreeTTS processing point. The Voice uses a FreeTTSSpeakable as its input, transforms the text connected with the FreeTTSSpeakable into expression and produces the respective video output. The Voice is FreeTTS ' main customization point. Customizations of language, speaker, and algorithm can all be accomplished by expanding the speech. A Voice will use the Voice.speak technique and procedure to recognize a FreeTTSSpeakable, where the Voice transforms a FreeTTSSpeakable into a sequence of Utterances. The standards usually depend on language for breaking a FreeTTSSpeakable into a Utterance. For example, an English Voice may choose to break a FreeTTSSpeakable into Utterances based on sentence breaks. As each Utterance is generated by the Voice, the Utterance is processed by a number of UtteranceProcessors. Each voice describes its own number of processors for Utterance. For example, a Voice would simply supply a new UtteranceProcessor that implements the new algorithm to change how units are joined together during the synthesis process. UtteranceProcessor typically runs, annotate or modify the Utterance with data in turn. For example, a UtteranceProcessor ' Phrasing' may add sentence labels into a Utterance indicating where a spoken sentence starts. The Voice brings the Utterance to the AudioOutputUtteranceProcessor once all Utterance handling has been implemented. In order to allow Utterance processing to overlap with audio production, the AudioOutput processor can operate in a distinct thread to ensure the smallest feasible noise latency [22-25].

\section{Wii mote as Air Mouse}

The VR device-Wiimote has been converted to the Air Mouse with the help of the GlovePie. Initially the wiimote is connected to the laptop, using the Bluetooth. When the wiimote gets paired with the laptop, with the Glovepie, it has been converted as a mouse. Here the Wiimote has been used as the mouse, for selecting the objects in the virtual environment. This makes the students to actively involve in the learning process [26].

\section{CASE STUDY}

\section{A. Acid rain}

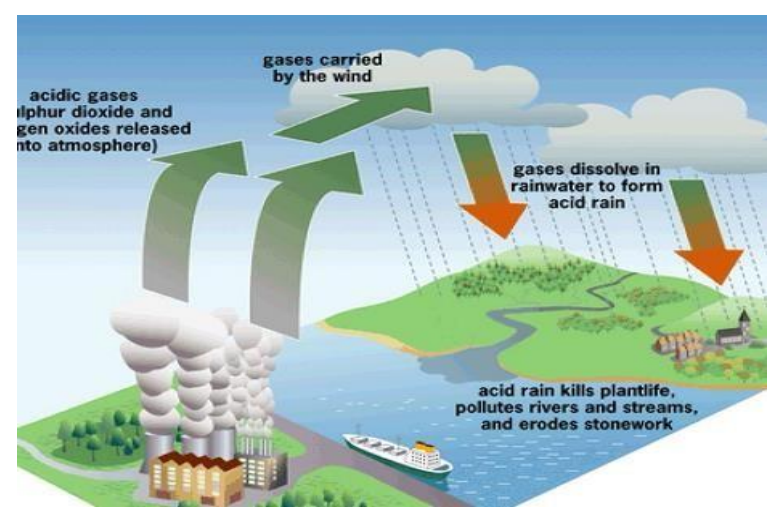

Fig a: Explanation of Acid Rain through picture

In order to explain the concepts of acid rain, initially the student is allowed to burn the fossil fuel such as coal in the virtual world, with the help of the wiimote, just by selecting it. When this burns, the student experiences the vibrating effect in their hand, which is produced by the wiimoteSo it produces sulfur dioxide and nitrogen oxides into the atmosphere when the coal is burned. These materials can grow very fast in the atmosphere, mixing and 
reacting with water, oxygen, and other chemicals to create more acidic pollutants, recognized as acid rain. All these contents which has been given in the text, where it will be converted as speech during the learning process. Thus the student receives the speech as the output [27].

\section{B. Crack in the rock}

Wear off rocks gradually, which is called weathering. Weathering of three kinds: physical weathering, chemical weathering, and biological weathering. Here the freeze-thaw process in the physical weathering has been explained along with the picture, user interaction and speech output in the virtual environment.

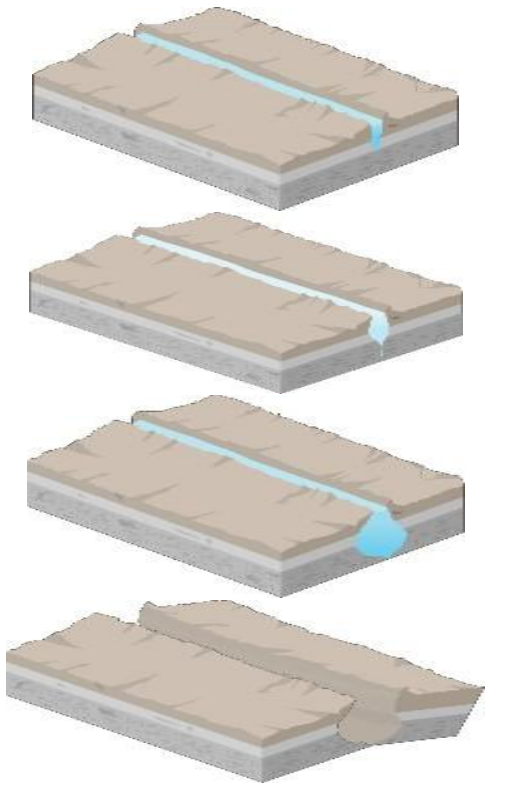

Fig b: Crack in the Rock

Water comes into the hole in a rock in the first figure. The water is freezing and expanding in the second, making the fracture larger. Water gets further into the hole in the middle, making it bigger. This drying and thawing method can proceed until the crack becomes so large that a piece of rock breaks off, as shown in the fourth figure. For the learning process, the virtual object such as rock has been created. Then the student is allowed to pour the water to the certain limit in the rock through the wiimote, initially for the first step(by selecting the button), after exceeding certain limit, the rock breaks automatically. So when the student is directly involving in this process with the help of the interaction, these concepts will remain in their memory for long time and also it forces them to learn more without any learning pressure [28].

\section{GRAVITY CONCEPT THROUGH SIMULATION}

Gravity is the force attracting two bodies to each other, the force causing apples to drop to the floor, and the planets to orbit the sun. The bigger an item is, the greater its tug of gravity. Thus the concept of gravity has been explained here along with the simulation.

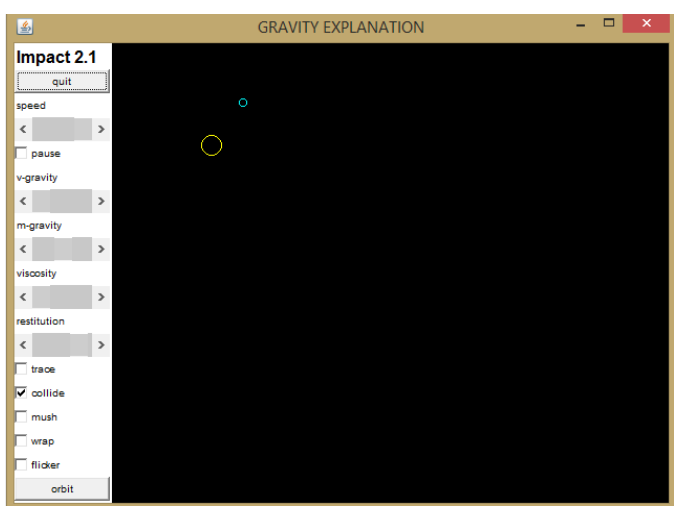

Fig c: Explanation of gravity through simulation

The Zero gravity is that, which involves the situation of obvious weightlessness that occurs when a body passes in a gravity field to counterbalance its gravity force. For instance, astronauts orbiting earth in a space station experience zero gravity as the spacecraft accelerates continually in its orbit to avoid it from being drawn into the atmosphere. This acceleration is reffered to as the centrifugal force, that counter balances the gravity exactly. Considering this example, the simulation is shown in the fig-c, here the ball remains orbiting, where it gives the complete explanation about the above concept $[29,30]$.

\section{CONCLUSION}

In this paper, the importance of virtual reality in education has been explained along with the case study. This game based learning provides the concepts to the students more accurately, and also it delivers the concepts clearly to the blind people because of the speech synthesis, where it helps them to learn without others help. Thus when this virtual reality based education has been implemented in the schools, it lifts the education level one step higher in the future.

\section{REFERENCES}

1. Gowri Sankaran, B., Karthik, B. \& Vijayaragavan, S.P. 2019, "Weight ward change region plummeting change for square based image huffman coding", International Journal of Innovative Technology and Exploring Engineering, vol. 8, no. 10, pp. 4313-4316.

2. Gowri Sankaran, B., Karthik, B. \& Vijayaragavan, S.P. 2019, "Image compression utilizing wavelet transform", International Journal of Innovative Technology and Exploring Engineering, vol. 8, no. 10, pp. 4305-4308.

3. Kandavel, N. \& Kumaravel, A. 2019, "Offloading computation for efficient energy in mobile cloud computing", International Journal of Innovative Technology and Exploring Engineering, vol. 8, no. 10, pp 4317-4320.

4. Vinoth, V.V. \& Kanniga, E. 2019, "Reversible data hiding in encrypting images-an system", International Journal of Engineering and Advanced Technology, vol. 8, no. 6, pp. 3051-3053.

5. Selvapriya, B. \& Raghu, B. 2019, "Pseudocoloring of medical images: A research", International Journal of Engineering and Advanced Technology, vol. 8, no. 6, pp. 3712-3716.

6. Senthil Kumar, K. \& Muthukumaravel, A. 2019, "Bi-objective constraint and hybrid optimizer for the test case prioritization", International Journal of Engineering and Advanced Technology, vol. 8, no. 6, pp. 3436-3448.

7. Kavitha, G., Priya, N., Anuradha, C. \& Pothumani, S. 2019, "Read-write, peer-to-peer algorithms for the location-identity split", International Journal of Innovative Technology and Exploring Engineering, vol. 8, no. 9 Special Issue 3, pp. 445-447. 
8. Kaliyamurthie, K.P., Michael, G., Anuratha, C. \& Sundaraj, B. 2019, "Certain improvements in alzheimer disease classification using novel fuzzy c means clustering for image segmentation", International Journal of Innovative Technology and Exploring Engineering, vol. 8, no. 9 Special Issue 3, pp. 599-604.

9. Kaliyamurthie, K.P., Sundarraj, B., Geo, A.V.A. \& Michael, G. 2019, "RIB: Analysis of I/O automata", International Journal of Innovative Technology and Exploring Engineering, vol. 8, no. 9 Special Issue 3, pp. 1019-1022.

10. Velvizhi, R., Rajabhushanam, C. \& Vidhya, S.R.S. 2019, "Opinion mining for travel route recommendation using Social Media Networks (Twitter)", International Journal of Innovative Technology and Exploring Engineering, vol. 8, no. 9 Special Issue 3, pp. 508-512.

11. Kavitha, R., Sangeetha, S. \& Varghese, A.G. 2019, "Human activity patterns in big data for healthcare applications", International Journal of Innovative Technology and Exploring Engineering, vol. 8, no. 9 Special Issue 3, pp. 1101-1103.

12. Pothumani, S., Anandam, A.K., Sharma, N. \& Franklin, S. 2019, "Extended VEOT framework - Implemented in a smart boutique", International Journal of Innovative Technology and Exploring Engineering, vol. 8, no. 9 Special Issue 3, pp. 762-767.

13. Kaliyamurthie, K.P., Michael, G., Krishnan, R.M.V. \& Sundarraj, B. 2019, "Pseudorandom techniques for the internet", International Journal of Innovative Technology and Exploring Engineering, vol. 8, no. 9 Special Issue 3, pp. 915-918.

14. Aravindasamy, R., Jeffrin Rajan, M., Rama, A. \& Kavitha, P. 2019, "Deep learning provisions in the matlab: Focus on CNN facility", International Journal of Innovative Technology and Exploring Engineering, vol. 8, no. 9 Special Issue 3, pp. 990-994.

15. Theivasigamani, S., Linda, M. \& Amudha, S. 2019, "Object sensing and its identification \& motion sensing", International Journal of Innovative Technology and Exploring Engineering, vol. 8, no. 9 Special Issue 3, pp. 545-549.

16. Mary Linda, I., Vimala, D. \& Shanmuga Priya, K. 2019, "A methodology for the emulation of IPv4", International Journal of Innovative Technology and Exploring Engineering, vol. 8, no. 9 Special Issue 3, pp. 848-852.

17. Velvizhi, R., Priya, D.J., Vimala, D. \& Linda, I.M. 2019, "Increased routing algorithm for mobile adhoc networks", International Journal of Innovative Technology and Exploring Engineering, vol. 8, no. 9 Special Issue 3, pp. 1606-1608.

18. Sangeetha, S., Anuradha, C. \& Priya, N. 2019, "DNS in real world", International Journal of Innovative Technology and Exploring Engineering, vol. 8, no. 9 Special Issue 3, pp. 937-940.

19. Geetha, C., Vimala, D. \& Priya, K.S. 2019, "Constructing multi-processors and spreadsheets with SKIVE", International Journal of Innovative Technology and Exploring Engineering, vol. 8, no. 9 Special Issue 3, pp. 516-519.

20. Yugendhar, K., Sugumar, V. \& Kavitha, P. 2019, "A novel method of univac using fuzzy logic", International Journal of Innovative Technology and Exploring Engineering, vol. 8, no. 9 Special Issue 3, pp. 435-437.

21. Kaliyamurthie, K.P., Michael, G., Elankavi, R. \& Jijo, S.A. 2019, "Implementing aggregate-key for sharing data in cloud environment using cryptographic encryption", International Journal of Innovative Technology and Exploring Engineering, vol. 8, no. 9 Special Issue 3, pp. 957-959.

22. Jeffrin Rajan, M., Aravindasamy, R., Kavitha, P. \& Rama, A. 2019, "A novel method of object orientation variation in $\mathrm{C}++$ and java", International Journal of Innovative Technology and Exploring Engineering, vol. 8, no. 9 Special Issue 3, pp. 708-710.

23. Nayak, R., Dinesh, S. \& Thirunavukkarasu, S. 2019, "A novel method improvement of rapid miner for the data mining applications", International Journal of Innovative Technology and Exploring Engineering, vol. 8, no. 9 Special Issue 3, pp. 457-460.

24. Sivaraman, K., Krishnan, R.M.V., Sundarraj, B. \& Sri Gowthem, S. 2019, "Network failure detection and diagnosis by analyzing syslog and SNS data: Applying big data analysis to network operations", International Journal of Innovative Technology and Exploring Engineering, vol. 8, no. 9 Special Issue 3, pp. 883-887.

25. Vimala, D., Linda, I.M. \& Priya, K.S. 2019, "Decoupling online algorithms from erasure coding in DNS", International Journal of Innovative Technology and Exploring Engineering, vol. 8, no. 9 Special Issue 3, pp. 950-953.

26. Rama, A., Kumaravel, A. \& Nalini, C. 2019, "Preprocessing medical images for classification using deep learning techniques", International Journal of Innovative Technology and Exploring Engineering, vol. 8, no. 9 Special Issue 3, pp. 711-716.
27. Sangeetha, S., Srividhya, S.R., Anita Davamani, K. \& Amudha, S. 2019, "A procedure for avoid overrun error in universal synchronous asynchronous receiver transmitter (usart) by utilizing dummy join and interrupt latency method", International Journal of Innovative Technology and Exploring Engineering, vol. 8, no. 9 Special Issue 3, pp. 657-660.

28. Aravindasamy, R., Jeyapriya, D., Sundarajan, B. \& Sangeetha, S. 2019, "Data duplication in cloud for optimal performance and security", International Journal of Innovative Technology and Exploring Engineering, vol. 8, no. 9 Special Issue 3, pp. 1156-1158.

29. Aravindasamy, R., Jeffrin Rajan, M., Sugumar, V. \& Kavitha, P. 2019, "A novel method on developing superblocks and the transistor using apodryal", International Journal of Innovative Technology and Exploring Engineering, vol. 8, no. 9 Special Issue 3, pp. 982-985.

30. Sasikumar, C.S. \& Kumaravel, A. 2019, "E-learning attributes selection through rough set theory and data mining", International Journal of Innovative Technology and Exploring Engineering, vol. 8 , no. 10 , pp. 3920-3924.

\section{AUTHORS PROFILE}

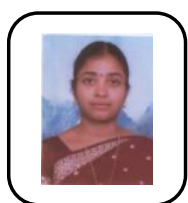

S. Pothumani, Assistant Professor, Department of Computer Science \& Engineering, Bharath Institute of Higher Education and Research, Chennai, India

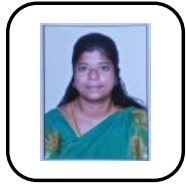

R. Velvizhi, Assistant Professor, Department of Computer Science \& Engineering, Bharath Institute of Higher Education and Research, Chennai, India

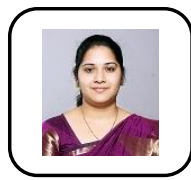

S. Amudha, Assistant Professor, Department of Computer Science \& Engineering, Bharath Institute of Higher Education and Research, Chennai, India 